\title{
Fishes in a California coastal lagoon: effects of major storms on distribution and abundance
}

\author{
Christopher P. Onuf and Millicent L. Quammen
}

Marine Science Institute, University of California, Santa Barbara, California 93106, USA

\begin{abstract}
Monthly beach seine samples were collected at 4 sites in the eastern arm of Mugu Lagoon, USA, from February 1977 to February 1982. The seasonal pattern of maximum abundance in spring or early summer and highest diversity in autumn is similar to reports for other regions. Declines in abundance and number of species, increases in Shannon-Weaver diversity and evenness, and alterations in the distribution of the total monthly catches among stations were evident over the 5-yr study. Most of the annual changes in the populations of fishes could be explained by major storms at the beginning of the second and fourth years of the study. Thick blankets of new, fine sediments differentially affected the sampling sites of the previously mostly sandy lagoon. Topsmelt Atherinops affinis and shiner surfperch Cymatogaster aggregatus, the 2 dominant species of Year 1 (accounting for $42 \%$ and $34 \%$ of total catch, respectively), suffered heavier reductions in number than the other common species. Species that spend the majority of their time in the water column were adversely affected to a greater extent than bottom-dwelling species. The disproportionate effects on watercolumn compared to bottom-dwelling species appear to result from the substantial reduction of the low tide volume of the lagoon, especially in the deepest parts, and the destruction of the eelgrass bed that originally covered most of the lagoon. The role of rare, very large natural disturbances may be important in most shallow water marine systems. The role of sedimentation in causing irreversible change as well as disturbance will apply to the small embayments along steep coastlines in regions with Mediterranean climates.
\end{abstract}

\section{INTRODUCTION}

Periodic sampling of a biota over a complete year provides valuable information about composition, abundance, seasonal changes in composition and abundance, and habitat associations. When sampling extends over multiple years, these data become more useful by also providing a measure of the annual variability or, conversely, the consistency of biotic patterns. If such sampling encompasses environmental extremes, changes in the biota can almost certainly be associated with extensive changes in the environment in ways that will reveal, or at least strongly suggest, the causes of the observed dynamics of the system.

We have witnessed 2 major natural environmental perturbations during a 5-yr study of the fish fauna of a shallow embayment fringed by a salt marsh at Mugu Lagoon, Ventura County, California, USA. The winter of 1978 was the second wettest rainy season in $113 \mathrm{yr}$ of local meteorological records. It followed $3 \mathrm{yr}$ of below- average rainfall and deposited as much as $50 \mathrm{~cm}$ of fresh sediments in the deepest parts of the lagoon. The second major perturbation occurred in the winter of 1980. Although precipitation was less over the whole season than in 1978 , over $17 \mathrm{~cm}$ of rain fell in one $40-\mathrm{h}$ period (Steffen, 1982). Levees were broken on the major inlet stream and another thick mantle of sediments was deposited in the lagoon. Thus, we have a 'replicated' documentation of a normally rare, very severe environmental disturbance.

Our analysis of fish community dynamics in this estuarine system begins with a general description of the changes in abundance, variety and distribution of fishes over a 5-yr period. It proceeds to a site-specific description of the environmental changes that occurred during the study. Then it analyzes the changes in the fish community in light of the observed sitespecific alterations of the lagoon environment. The report concludes by suggesting which aspects of the observed dynamics will generalize to many other 
shallow water marine systems and which will be restricted to other geographically and climatically similar situations. Within this more restricted subset, especially the small and isolated coastal wetlands of the southwestern Pacific coast of the United States, coastal wetlands are already rare and threatened ecosystems (California Coastal Zone Conservation Commissions, 1975). Therefore, the documentation of the effects of severe episodic sedimentation as provided by this study should be valuable in guiding the management of these systems (Onuf, 1980).

\section{SITE DESCRIPTION AND METHODS}

The study was carried out in the eastern arm of Mugu Lagoon $\left(34^{\circ} 06^{\prime} \mathrm{N}, 119^{\circ} 05^{\prime} \mathrm{W}\right)$ which lies within the boundaries of the US Naval Air Station at Pt. Mugu, California (Fig: 1). The eastern arm of the lagoon consists of -50 ha of wetland habitats, of which one half is emergent salt marsh dominated by Salicornia virginica, one quarter are intertidal sand and mud flats, and one quarter is permanently covered by water. The lagoon and its fringing salt marsh is bounded on the north by the steep flank of the Santa Monica Mountains and on the south by a narrow, sparsely vegetated sandspit. The mouth of the lagoon has been continuously open to the Pacific Ocean since at least 1976 .

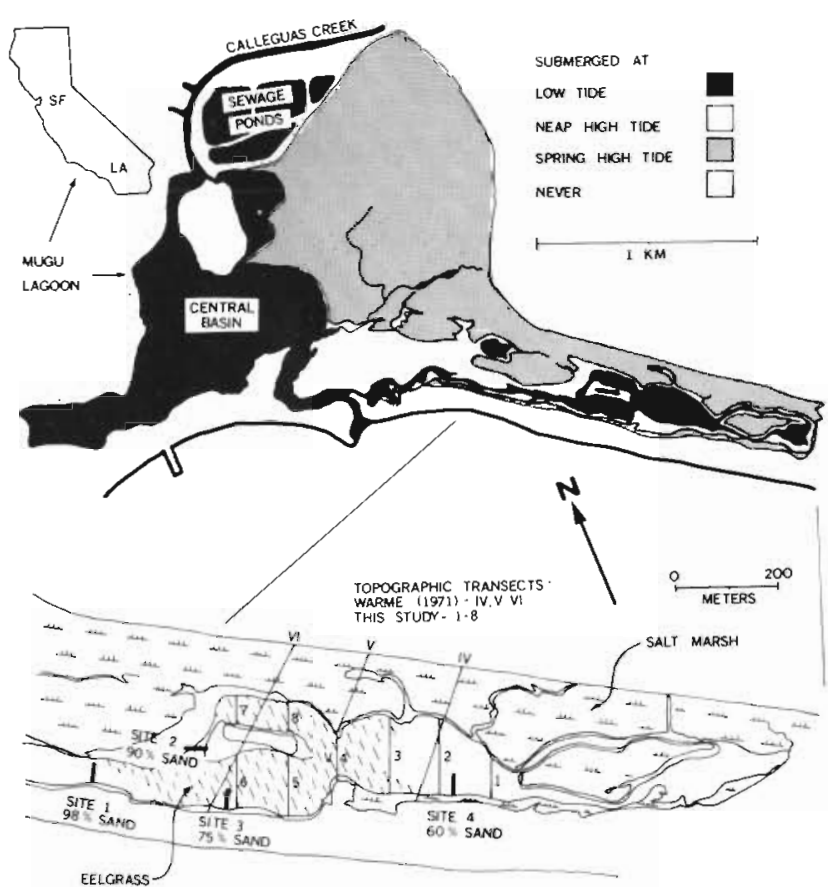

Fig. 1. Maps of the central basin and eastern arm of Mugu Lagoon showing areas flooded by different tides (top) and sampling sites, topographic transects (see Table 2) and major features (bottom) in 1977 (cf. Fig. 5). Inset: location of Mugu Lagoon in California, USA
The eastern arm has been well studied. Warme (1971) and Macdonald (1976) described the geology, surrounding land use and relations of the lagoon to its watershed, and the biota. Plant cover (Onuf, in prep.), primary production (Onuf et al., 1979; Onuf, in prep.) and the shelled macro-invertebrates (Warme, 1971; Peterson, 1977; Peterson and Andre, 1980) have been well studied. Species lists have been reported for other groups (MacGinitie and MacGinitie, 1969; Macdonald, 1976), and Onuf, et al. (1979) provided a report of the total catch of fishes by species for the first nineteen months of this study.

All fish were caught with a $15-\mathrm{m}$ long by $2-\mathrm{m}$ deep beach seine with a $2 \mathrm{~m}$ by $2 \mathrm{~m}$ bag. When stretched, the mesh measured $1.0 \mathrm{~cm}$. We set the seine from a rowboat and hauled it to shore from a distance of $40 \mathrm{~m}$. The mouth of the seine measured $\sim 10 \mathrm{~m}$ when used in this manner. We sampled the same 4 sites once a month for 60 mo from February $197 \bar{f}$ to February 1981 , except as noted in Fig. 2. All samples were taken in daylight, usually between 1000 and 1700 local time, on moderate to high tides so that we could sample the intertidal portions of the sites.

For the first year of the study, the characteristics of the sampling sites were as indicated in Fig. 1. Proceeding from west to east and progressively further from the mouth of the lagoon, Site 1 was a sandy bottom intertidal to shallow subtidal area $(<0.3 \mathrm{~m}$ on most low tides) subject to relatively strong tidal currents except for a few minutes at the turning of the tides. Eelgrass was limited to one intertidal bed, $\sim 5 \mathrm{~m}^{2}$ in area. Site 2 was a muddy sandflat covered by no more than $0.2 \mathrm{~m}$ of water on low tides. Eelgrass covered the subtidal parts. Current velocities were low for at least the $3 \mathrm{~h}$ of slack water at all low tides. This period could be prolonged up to a few days during some neap tide periods. Currents were moderate at higher-water levels. Site 3 was almost entirely subtidal, averaged $0.6 \mathrm{~m}$ in depth on the lowest tides, and was densely covered with eelgrass. Tidal currents were moderate. Site 4 averaged $0.5 \mathrm{~m}$ depth on the lowest tides. The bottom was fine textured compared to the other sites (40\% mud) and bare except for a few eelgrass plants and cover by filamentous red and green algae briefly in the autumn. Tidal currents were less apparent than at any other sampling site.

The aggregating behavior of most fish species (Oviatt and Nixon, 1973) and their distinct seasonality, at least in temperate coastal waters, hamper the use of parametric statistical analyses. A non-parametric technique overcame these difficulties. By ranking our monthly statistics and comparing statistics between catches of the same rank for different years, we have been able to perform significance tests on whether or not years are different and in what direction, for the 
Fig. 2. Monthly statistics for total catch of fishes from 4 sites in the eastern arm of Mugu Lagoon, February 1977 to February 1982. (a) Total abundance (N) (left axis) and number of species (S) (right axis). (b) Shannon-Weaver index of diversity

$$
\mathrm{H}=\Sigma \frac{\mathrm{n}_{\mathrm{i}}}{\mathrm{N}} \ln \left(\frac{\mathrm{n}_{\mathrm{i}}}{\mathrm{N}}\right)
$$

where $n_{i}=$ abundance of the $i$ 'th species; evenness $\mathrm{J}^{\prime \prime}=\mathrm{H}^{\prime \prime} / 1 \mathrm{nS}$. (c) Number of individuals of common species caught each month during the study. "Samples not collected at Site 1 in June 1977; Site 2 in February, May, June 1977, and Site 4 in March 1978. Catches for these months were deleted for these sites in all other sites in all other years for the statistical analyses

whole lagoon, the different sites and the common species, respectively. The procedure consists of calculating the binomial probability that the signs of the 12 differences between catch statistics of the same rank would be apportioned as observed. The procedure is demonstrated in Table 1A, B: 11 of the 12 monthly catches of Year 1 are larger than the catches of similar rank in Year 2. The probability that the 2 years are not different in this case is so small $(p=0.006)$ that the monthly catches of Year 1 can be safely concluded to be larger than in Year 2. Short-term and persistent effects of major storms on the fish community can be distinguished by these tests because of the fortuitous occurrence of the major storms in Years 2 and 4 . Thus, significant differences between adjacent years would indicate short-term storm effects (main diagonal, Table 1B) and significant differences among Years 1, 3 and 5 or between Years 2 and 4 would indicate persistent storm effects (second main diagonal and upper right corner, i.e. failure to return to prior conditions in subsequent years of same kind). The entries on the third diagonal are not considered, because they confound the different possibilities of short-term, persistent or no effect.

\section{RESULTS}

\section{Catch statistics for the whole lagoon}

Monthly catches for the whole lagoon showed one peak in abundance in May or June and a second peak
- tear 2 year 3 year a tear 5
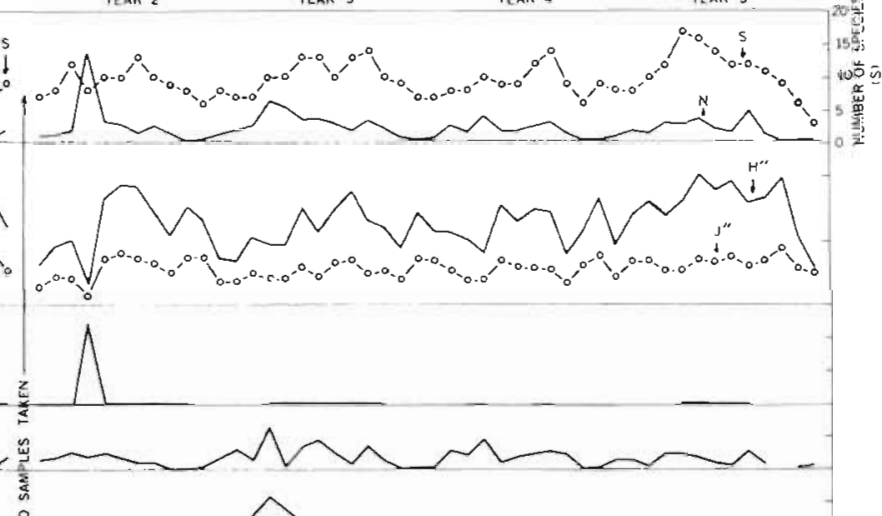

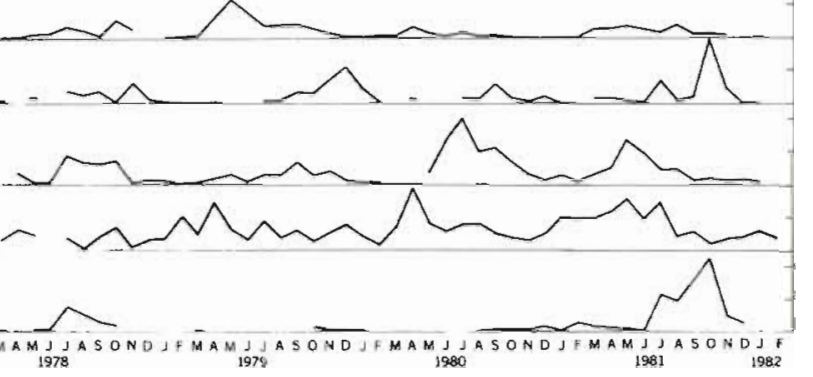

in September, October or November in all $5 \mathrm{yr}$ of the study (Fig. 2a). The peaks were more pronounced in the first 2 yr than later. All possible 2-way comparisons between ranked monthly catches for different years indicate both short-term and persistent effects of major storms (Table 1A, B). All year-to-year differences were significant, with abundances down in major storm years (2 and 4) compared to minor storm years (1,3 and 5). Recovery in subsequent minor storm years was not complete, because a net decline is apparent over the whole study (Year 1 to Year 5) as well as between Years 3 and 5, all minor storm years.

The number of species caught in a month was lowest sometime between December and April and highest sometime between May and November, depending on the year (Fig. 2a). Binomial comparisons between the number of species caught in months of the same rank in different years reveal the same pattern as for abundance (Table 1B, C), indicating that the major storms caused short-term declines in the number of species that were not compensated completely in subsequent minor storm years.

The Shannon-Weaver index of diversity varied erratically but with somewhat diminished amplitude later in the study (Fig. 2b). Highest values were reached in July, August or October depending on the year. Values were lower in Years 2, 3, 4 that Year 1 and then rose to the highest levels observed during the study in Year 5 (Table 1D). Peak abundances often corresponded with very low diversity values, suggesting heavy dominance by one or a few species at these times (note in Figs. 2a, b, OND 1977 and MJJ 1978 especially). The 
Table 1 Statistical analyses on catch statistics for the whole lagoon. (A) Example of the procedure for performing binomial probability tests on the signs of the differences between months of the same rank in different years. Total numbers caught in each month of Year 2 compared to Year 1 are used in the example. The boxed couplet in (B) is the final result of this comparison. (B-E) The results for the various catch statistics analyzed. Means, the number of same-ranked months in the column year that exceeded $(+)$ or are less than $(-)$ the row year and summaries of significant differences between years appear from left to right in the table. - $p<0.05, \cdots p<0.01, \cdots p<0.001$. Underlined differences are in the wrong direction for the interpretation of storm-caused short-term or persistent declines

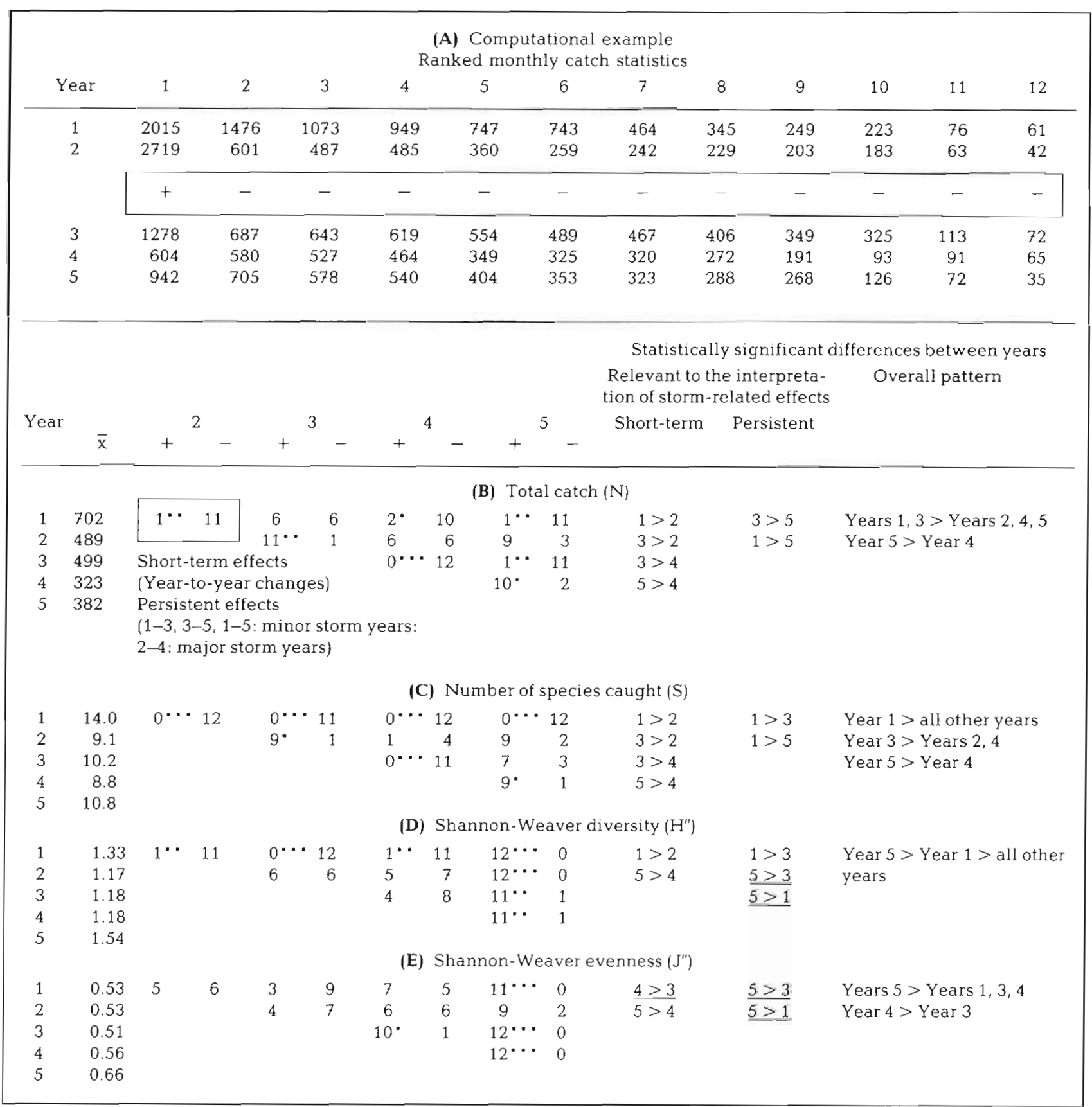

correspondingly low measures of evenness ( $\mathrm{J}^{\prime \prime}$, Fig. 2b) are consistent with this interpretation. Evenness did not vary significantly during the first 3 yr but increased from Year 3 to Year 4 and again to Year 5 (Table $1 \mathrm{E}$ ). The increase from Year 1 to Year 5 was very highly significant (Table $1 \mathrm{E}$ ).
In summary, annual changes in abundance and number of species were closely correlated with the occurrence of major storms. Reductions persisted more than 1 yr. Changes in Shannon-Weaver diversity and evenness were not simply related to the occurrence of storms. The reasons for this will be discussed later. 


\section{Changes in site characteristics during the study}

During the storm of 5 to 12 February, 1978, large amounts of new, fine sediments were deposited in the eastern arm of Mugu Lagoon. Based on our surveys of 4 cross-sections of the lagoon originally reported in Warme (1966) (Fig. 1), we estimate that on average $13 \mathrm{~cm}$ of new sediments were deposited (Table 2A). This caused a $25 \%$ reduction in the low tide depth for these sites.

The eftects ot the storm were different at the different beach seining sites. At Site 1 the changes were short-lived. Within 3 mo, surface sediment composition was almost as sandy as it had been before the storm, even though there had been a 10-fold increase in silt and clay content during the storm period (Fig. 3). In contrast, Site 2 did not revert to its previous, predominantly sandy, condition (Fig. 3). In addition, the eelgrass that had covered the shallow subtidal portion of Site 2 was completely buried and remained so for the rest of the study. Site 3 received a thick layer of sediments, but because the eelgrass grew much longer in the deep water of this location, it survived the initial inundation. However, the bed deteriorated thereafter, until none was present at the end of the summer of 1978. The covering of new, fine sediments at Site 4 was deep and has persisted. Because this site was the muddiest initially (based on Warme, 1966, sediment analyses, and Cermak, unpubl.), the addition of new

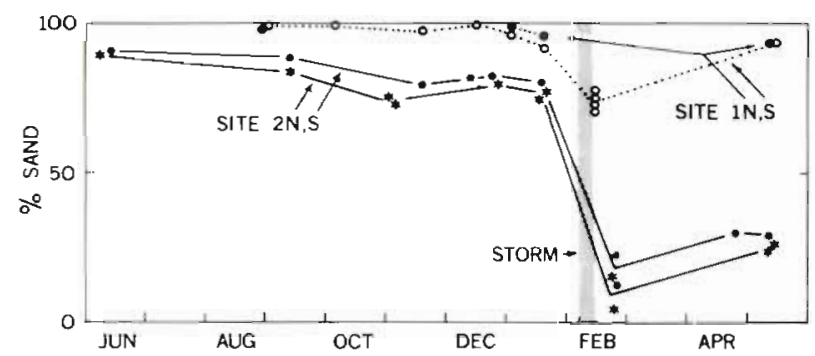

Fig. 3. Percent sand of surface sediment layer before, during and after the storm of 5 to 12 February 1978 at the northern (N) and southern (S) ends of Sites 1 and 2 respectively

fine sediments may have changed it little as habitat for fish or invertebrates.

The major flood of 1980 also caused heavy sedimentation in the eastern arm of Mugu Lagoon (Table 2B). Based on more extensive surveys that were available for the 1978 episode of sedimentation, we documented average accumulations from 1.5 to $11 \mathrm{~cm}$ along 8 crosssections at $100 \mathrm{~m}$ intervals in the lagoon (Fig. 1). For the lagoon as a whole, this amounted to a $17 \%$ decrease in average depth. There was no apparent change in the substrate characteristics of any of the sampling sites. Cover by eelgrass in the lagoon has increased gradually since 1979 but in 1982 was still much reduced compared to the beginning of the study, except at Site 1. There between 1979 and 1982 a dense eelgrass bed of $\sim 80 \mathrm{~m}^{2}$ had grown up. This is a 20 -fold increase in cover by eelgrass at this site (Table 3 ).

Table 2. Changes in depth of eastern arm of Mugu Lagoon. (A) Mean depths below lowest water along 4 transects surveyed in the mid-1960's (Warme, 1966) and 30 September 1979. (B) Mean depths along 8 transects surveyed 30 September 1979 and 25 March 1980

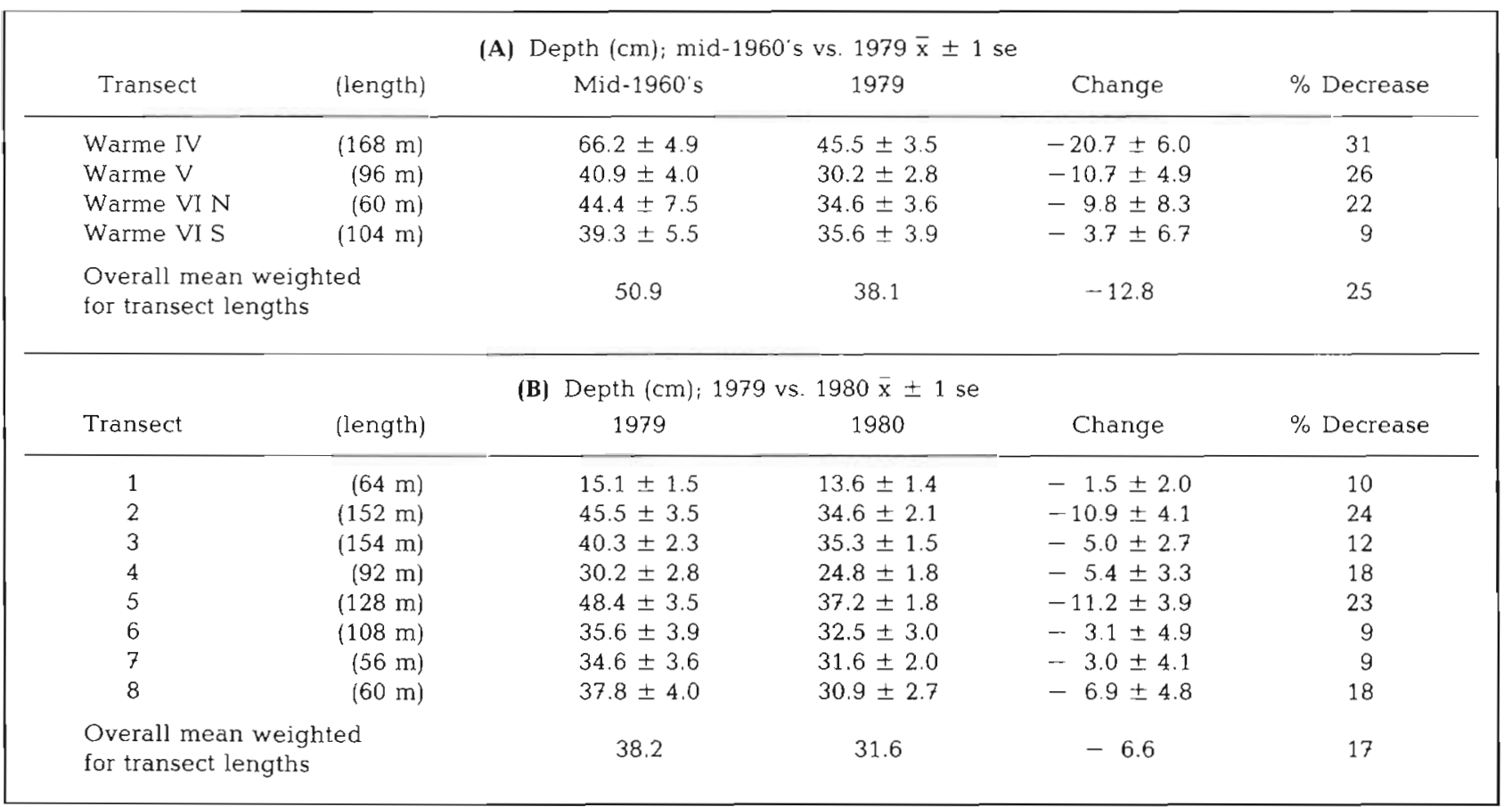


Table 3. Characteristics of the beach seining sites between February 1977 and February 1982

\begin{tabular}{|c|c|c|c|c|c|c|}
\hline & Site & Year 1 & $\begin{array}{l}\text { March } 1978 \\
\text { (after storm) }\end{array}$ & $\begin{array}{l}\text { End of } \\
\text { the study }\end{array}$ & $\begin{array}{l}\text { Extent of } \\
\text { change }\end{array}$ & \\
\hline Site 1 & $\begin{array}{l}\text { Bottom type } \\
\text { Maximum depth, low water } \\
\text { Vegetation }\end{array}$ & $\begin{array}{l}\text { Sand } \\
30 \mathrm{~cm} \\
1 \% \text { eelgrass }\end{array}$ & $\begin{array}{l}\text { Mud } \\
30 \mathrm{~cm} \\
1 \% \text { eelgrass }\end{array}$ & $\begin{array}{l}\text { Sand } \\
30 \mathrm{~cm} \\
20 \% \text { eelgrass }\end{array}$ & $\begin{array}{l}\text { Large, transitory } \\
\text { Small } \\
\text { Small }(+)\end{array}$ & Least \\
\hline Site 2 & $\begin{array}{l}\text { Bottom type } \\
\text { Maximum depth, low water } \\
\text { Vegetation }\end{array}$ & $\begin{array}{l}\text { Muddy sand } \\
20 \mathrm{~cm} \\
50 \% \text { eelgrass }\end{array}$ & $\begin{array}{l}\text { Mud } \\
10 \mathrm{~cm} \\
\text { Seasonal } \\
\text { macroalgae }\end{array}$ & $\begin{array}{l}\text { Mud } \\
5 \mathrm{~cm} \\
\text { Seasonal } \\
\text { macroalgae }\end{array}$ & $\left.\begin{array}{l}\text { Large } \\
\text { Large }(-) \\
\text { Large, immediate }\end{array}\right\}$ & Most \\
\hline Site 3 & $\begin{array}{l}\text { Bottom type } \\
\text { Maximum depth, low water } \\
\text { Vegetation }\end{array}$ & $\begin{array}{l}\text { Muddy sand } \\
80 \mathrm{~cm} \\
100 \% \text { eelgrass }\end{array}$ & $\begin{array}{l}\text { Mud } \\
65 \mathrm{~cm} \\
100 \% \text { eelgrass }\end{array}$ & $\begin{array}{l}\text { Mud } \\
50 \mathrm{~cm} \\
\text { Bare }\end{array}$ & $\begin{array}{l}\text { Small? } \\
\text { Large }(-) \\
\text { Large, gradual }\end{array}$ & Most \\
\hline Site 4 & $\begin{array}{l}\text { Bottom type } \\
\text { Maximum depth, low water } \\
\text { Vegetation }\end{array}$ & $\begin{array}{l}\text { Muddy sand } \\
70 \mathrm{~cm} \\
\text { Seasonal } \\
\text { macroalgae }\end{array}$ & $\begin{array}{l}\text { Mud } \\
50 \mathrm{~cm} \\
\text { Seasonal } \\
\text { macroalgae }\end{array}$ & $\begin{array}{l}\text { Mud } \\
40 \mathrm{~cm} \\
\text { Seasonal } \\
\text { macroalgae }\end{array}$ & $\begin{array}{l}\text { Small } \\
\text { Large (-) } \\
\text { Small }\end{array}$ & Intermediate \\
\hline
\end{tabular}

In summary, at Site 1 cover by eelgrass increased. At Sites 2 and 3 the depth of water decreased, the texture of the substrate became finer, and the eelgrass bed was destroyed. At Site 4 the depth of water decreased.

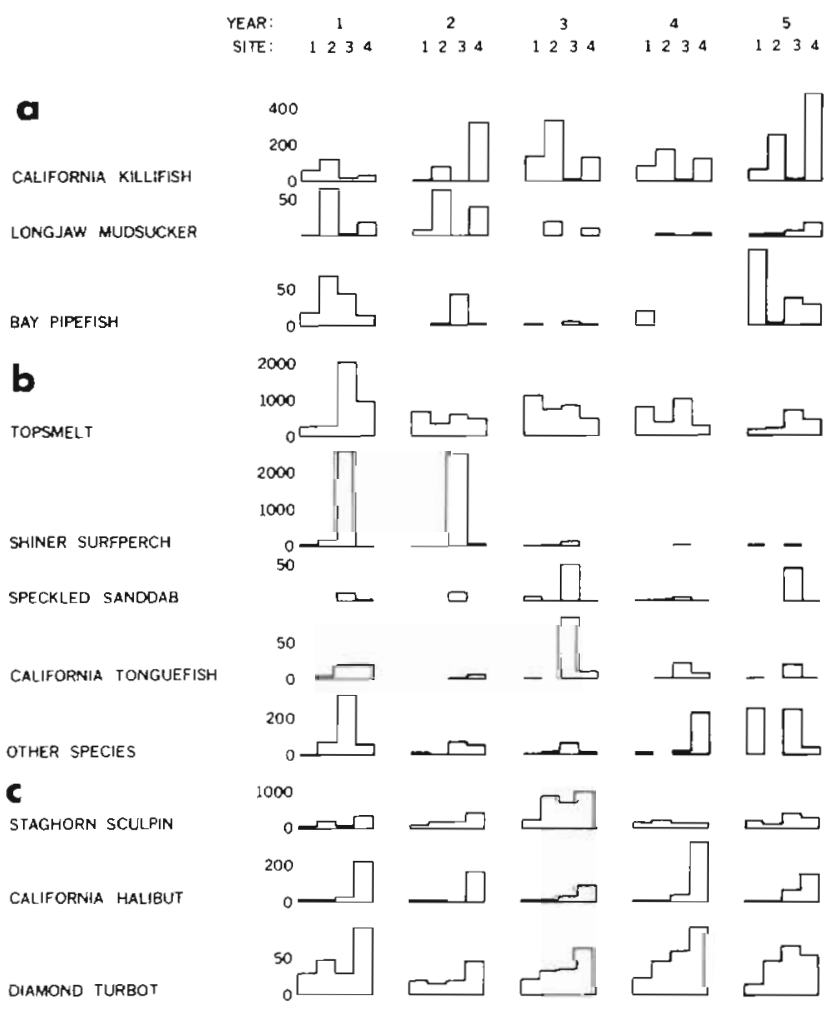

Fig. 4. Yearly catches of abundant species at different sites, arranged according to the site at which the species were most commonly caught in the first year of the study $(=$ site associates). (a) Site 2 associates. (b) Site 3 associates. (c) Site 4 associates

\section{Site specific changes in the fish community}

We now consider changes in the fish fauna on a site by site basis. This should reveal whether substrate and eelgrass cover are major predictive variables for fish abundance and distribution, since the extent of change caused by the storms differed greatly among sites. For each site, binomial comparisons between same-ranked months in different years were made on total number caught, number of species caught and number of individuals of each of the common species caught. The common species were classified according to the sites at which they were most commonly caught as 'site associates'. Associations were considered strong when more than twice as many individuals were caught at one site as any other site. Year-to-year and persistent effects of the storms were distinguished as illustrated in Table $1 \mathrm{~A}, \mathrm{~B}$.

At Site 1, differences between years in general do not suggest storm-related effects (Table 4A, E). Only the decline in number of species from Year 1 to Year 2 was consistent with a short-term storm effect. The lack of change in both abundance and number of species between Year 1 and Year 5, despite 2 major storms occurring during the intervening years, and the higher numbers present in Year 3 than most other years, argues against either persistent or cumulative storm effects. There were no Site 1 associates in Year 1; however, the bay pipefish Syngnathus leptorhynchus was strongly associated with the site in Years 4 and 5 (Fig. 4a).

At Site 2, the 4 significant year-to-year changes in abundances and number of species were all consistent with short-term storm-related effects (declines in major 
Table 4. Binomial tests on the number (A-D) and number of species (E-H) caught at different sites in different years. See legend to Table 1 for detailed explanation of table organization

\begin{tabular}{|c|c|c|c|c|c|c|c|c|c|c|c|c|}
\hline \multirow{4}{*}{ Year } & \multirow[b]{4}{*}{$\overline{\mathrm{x}}$} & \multirow{4}{*}{\multicolumn{2}{|c|}{$\begin{array}{r}2 \\
+\quad-\end{array}$}} & \multirow{3}{*}{\multicolumn{2}{|c|}{3}} & \multirow{4}{*}{\multicolumn{2}{|c|}{$\begin{array}{r}4 \\
+\quad-\end{array}$}} & & & \multicolumn{3}{|c|}{ Statistically significant differences between years } \\
\hline & & & & & & & & & & \multicolumn{2}{|c|}{$\begin{array}{l}\text { Relevant to the interpreta- } \\
\text { tion of storm-related effects }\end{array}$} & \multirow[t]{3}{*}{ Overall pattern } \\
\hline & & & & & & & & \multicolumn{2}{|c|}{5} & Short-term & Persistent & \\
\hline & & & & + & - & & & + & - & & & \\
\hline \multicolumn{13}{|c|}{ (A) Number caught at Site 1} \\
\hline 1 & 46.4 & 5 & 6 & $11 \cdots$ & 1 & 8 & 2 & 8 & 3 & $3>2$ & $\underline{3>1}$ & Year $3>$ Years $1,2,5$ \\
\hline 2 & 70.8 & & & $12^{\cdots}$ & 0 & $11 \cdots$ & 1 & $10^{\circ}$ & 2 & & $3>5$ & Years $4,5>$ Year 2 \\
\hline 3 & 126.0 & & & & & 4 & 7 & $1 \cdots$ & 11 & & $\underline{4>2}$ & \\
\hline 4 & 88.6 & & & & & & & 4 & 8 & & & \\
\hline 5 & 83.3 & & & & & & & & & & & \\
\hline \multicolumn{13}{|c|}{ (B) Number caught at Site 2} \\
\hline 1 & 114.9 & $0 \cdots$ & 9 & 5 & 3 & $1^{*}$ & 8 & 2 & 7 & $1>2$ & & Year $1>$ Years 2, 4 \\
\hline 2 & 55.9 & & & $10^{\circ}$ & 2 & 9 & 3 & 8 & 4 & $3>2$ & & Year $3>$ Year 2 \\
\hline 3 & 164,6 & & & & & 3 & 9 & 3 & 8 & & & \\
\hline 4 & 65.6 & & & & & & & 8 & 4 & & & \\
\hline 5 & 82.5 & & & & & & & & & & & \\
\hline \multicolumn{13}{|c|}{ (C) Number caught at Site 3} \\
\hline 1 & 429.8 & $1 \cdots$ & 11 & $2^{\bullet}$ & 10 & $0^{\cdots}$ & - 12 & $0^{\cdots}$ & 12 & $1>2$ & $1>3$ & Year $1>$ all other years \\
\hline 2 & 283.8 & & & $11^{\cdots}$ & 1 & 6 & 6 & $10^{\circ}$ & 2 & $3>2$ & $1>5$ & Year $3>$ Years 2,4 \\
\hline 3 & 157.6 & & & & & $1 \cdots$ & 11 & 3 & 9 & $3>4$ & & Year $5>$ Year 2 \\
\hline 4 & 108.0 & & & & & & & 9 & 3 & & & \\
\hline 5 & 109.3 & & & & & & & & & & & \\
\hline \multicolumn{13}{|c|}{ (D) Number caught at Site 4} \\
\hline 1 & 145.1 & 5 & 6 & 8 & 4 & 3 & 9 & 3 & 8 & & $3>5$ & Years $2,3>$ Year 5 \\
\hline 2 & 139.4 & & & 6 & 5 & 2 & 9 & $1^{\cdots}$ & 9 & & & \\
\hline 3 & 148.9 & & & & & 3 & 9 & $2^{\bullet}$ & 10 & & & \\
\hline 4 & 95.8 & & & & & & & 9 & 3 & & & \\
\hline 5 & 129.2 & & & & & & & & & & & \\
\hline \multicolumn{13}{|c|}{ (E) Number of species caught at Site 1} \\
\hline 1 & 5.4 & $0^{\cdots}$ & 10 & $0 \cdots$ & 11 & $0^{\cdot}$ & 6 & 8 & 3 & $1>2$ & $1>3$ & Year $1>$ Years 2, 3, 4 \\
\hline 2 & 4.2 & & & 3 & 4 & 5 & 1 & $10^{\circ}$ & 1 & & & Year $5>$ Year 2 \\
\hline 3 & 4.2 & & & & & 6 & 1 & 9 & 2 & & & \\
\hline 4 & 4.6 & & & & & & & 9 & 2 & & & \\
\hline 5 & 6.2 & & & & & & & & & & & \\
\hline \multicolumn{13}{|c|}{ (F) Number of species caught at Site 2} \\
\hline 1 & 7.1 & $0^{\cdots}$ & 9 & $0 \cdots$ & 8 & $0 \cdots$ & 9 & $0 \cdots$ & 8 & $1>2$ & $1>3$ & Year $1>$ all other years \\
\hline 2 & 4.8 & & & 3 & 2 & $0^{*}$ & 6 & 2 & 7 & $3>4$ & $2>4$ & Years $2,3>$ Year 4 \\
\hline 3 & 4.8 & & & & & $1 \cdot$ & 8 & 1 & 6 & & $1>5$ & \\
\hline 4 & 4.0 & & & & & & & 6 & 2 & & & \\
\hline 5 & 4.2 & & & & & & & & & & & \\
\hline \multicolumn{13}{|c|}{ (G) Number of species caught at Site 3} \\
\hline 1 & 9.9 & $0 \cdots$ & 12 & $0 \cdots$ & 10 & $0 \cdots$ & $\cdot 12$ & $0 \cdots$ & 12 & $1>2$ & $1>3$ & Year $1>$ all other years \\
\hline 2 & 5.5 & & & $12 \cdots$ & 0 & 5 & 1 & $9^{*}$ & 0 & $3>2$ & $1>5$ & Year $3>$ Year 2,4 \\
\hline 3 & 8.1 & & & & & $0^{\cdots}$ & - 12 & 3 & 6 & $3>4$ & & Year $5>$ Year 2 \\
\hline 4 & 6.1 & & & & & & & 8 & 3 & & & \\
\hline 5 & 7.9 & & & & & & & & & & & \\
\hline \multicolumn{13}{|c|}{ (H) Number of species caught at Site 4} \\
\hline 1 & 7.2 & 2 & 9 & $1^{*}$ & 10 & 2 & 9 & $0 \cdots$ & 10 & & $1>3$ & Year $1>$ Years 3,5 \\
\hline 2 & 6.4 & & & 0 & 3 & $0 \cdots$ & 8 & 4 & 4 & & $2>4$ & Year $2>$ Year 4 \\
\hline 3 & 5.8 & & & & & 2 & 5 & 6 & 2 & & $1>5$ & \\
\hline 4 & 5.6 & & & & & & & 8 & 3 & & & \\
\hline 5 & 6.2 & & & & & & & & & & & \\
\hline
\end{tabular}

storm years, increases in minor storm years following major storm years, Table $4 \mathrm{~B}, \mathrm{~F}$ ). In addition, the declines in number of species from Year 1 to Year 3,
Year 2 to Year 4 and Year 1 to Year 5 all suggest persistent storm-related effects. All Site 2 associates in the beginning of the study had switched to other sites 
Table 5. Binomial tests on the number of individuals of the common species caught in the lagoon in different years. See legend to Table 1 for detailed explanation of table organization

\begin{tabular}{|c|c|c|c|c|c|c|c|c|c|c|c|c|}
\hline \multirow{3}{*}{ Year } & \multirow[b]{3}{*}{$\overline{\mathrm{x}}$} & \multirow{2}{*}{\multicolumn{2}{|c|}{2}} & \multirow{2}{*}{\multicolumn{2}{|c|}{3}} & \multirow{3}{*}{\multicolumn{2}{|c|}{4}} & \multirow{2}{*}{\multicolumn{2}{|c|}{5}} & \multicolumn{2}{|c|}{$\begin{array}{l}\text { Relevant to the interpreta- } \\
\text { tion of storm-related effects }\end{array}$} & \multirow[t]{3}{*}{ Overall pattern } \\
\hline & & & & & & & & & & Short-term & Persistent & \\
\hline & & + & - & + & - & & & + & - & & & \\
\hline \multicolumn{13}{|c|}{ (A) Topsmelt } \\
\hline 1 & 295.9 & $1 \cdots$ & 11 & 3 & 9 & 5 & 7 & $2^{\bullet}$ & 10 & $1>2$ & $4>2$ & Year $1>$ Years 2,5 \\
\hline 2 & 169.9 & & & 8 & 3 & $10^{\circ}$ & 1 & 5 & 7 & $1>5$ & $\overline{1>5}$ & Year $4>$ Year 5 \\
\hline 3 & 258.2 & & & & & 5 & 6 & 4 & 8 & & & \\
\hline 4 & 196.5 & & & & & & & $2^{\cdot}$ & 10 & & & \\
\hline \multicolumn{13}{|c|}{ (B) Shiner surfperch } \\
\hline 1 & 242.1 & $1^{\cdot}$ & 9 & $0 \cdots$ & 10 & $0^{*}$ & 10 & $0 \cdots$ & 10 & $1>2$ & $1>3$ & Year $1>$ Year $2>$ Years $3,4,5$ \\
\hline 2 & 220.8 & & & $1 \cdot$ & 9 & $0^{\cdots}$ & 10 & $0^{\cdots}$ & 10 & $2>3$ & $2>4$ & Year $3>$ Year 4 \\
\hline 3 & 9.9 & & & & & $0 \cdots$ & 8 & 1 & 7 & $\overline{3>4}$ & $1>5$ & \\
\hline 4 & 1.5 & & & & & & & 5 & 0 & & & \\
\hline \multicolumn{13}{|c|}{ (C) Staghorn sculpin } \\
\hline 1 & 50.6 & 5 & 7 & $11 \cdots$ & 1 & 3 & 7 & 4 & 8 & $3>2$ & $3>1$ & Year $3>$ all other years \\
\hline 2 & 71.3 & & & $12 \cdots$ & 0 & 4 & 7 & 8 & 2 & $3>4$ & $\overline{3>5}$ & \\
\hline 3 & 228.5 & & & & & $0^{\cdots}$ & 12 & $1 \cdots$ & 11 & & & \\
\hline 4 & 51.4 & & & & & & & 9 & 2 & & & \\
\hline \multicolumn{13}{|c|}{ (D) California killifish } \\
\hline 1 & 19.2 & $10^{\circ}$ & 2 & 8 & 4 & 7 & 4 & 8 & 2 & $2>1$ & & Year $2>$ Year 1 \\
\hline 2 & 34.7 & & & 5 & 5 & 2 & 8 & 8 & 3 & $3>4$ & & Years $3,5>$ Year 4 \\
\hline 3 & 50.7 & & & & & 1 . & 8 & 8 & 2 & $5>4$ & & \\
\hline 4 & 32.1 & & & & & & & $11^{\cdots}$ & 1 & & & \\
\hline \multicolumn{13}{|c|}{ (E) California halibut } \\
\hline 1 & 22.8 & 4 & 7 & 3 & 9 & 6 & 4 & 3 & 8 & $4>3$ & $4>2$ & Year $4>$ Years 2, 3, 5 \\
\hline 2 & 15.9 & & & 7 & 5 & $10^{\circ}$ & 1 & 9 & 2 & $4 \geq 5$ & $\overline{5>3}$ & Year $5>$ Year 3 \\
\hline 3 & 12.5 & & & & & $10^{\circ}$ & 2 & $10^{\circ}$ & 1 & & & \\
\hline 4 & 31.8 & & & & & & & $1 \cdot$ & 9 & & & \\
\hline \multicolumn{13}{|c|}{ (F) Diamond turbot } \\
\hline 1 & 16.2 & $0^{\cdots}$ & 12 & $0 \cdots$ & 12 & 5 & 3 & 4 & 6 & $1>2$ & $1>3$ & Years $1,4,5>$ Year $3>$ Year 2 \\
\hline 2 & 8.1 & & & $12 \cdots$ & 0 & $12 \cdots$ & 0 & $12 \cdots$ & 0 & $3>2$ & $4>2$ & \\
\hline 3 & 12.9 & & & & & $12 \cdots$ & 0 & $11 \cdots$ & 0 & $4>3$ & $5>3$ & \\
\hline 4 & 18.1 & & & & & & & 4 & 7 & & & \\
\hline \multicolumn{13}{|c|}{ (G) Bay pipefish } \\
\hline 1 & 11.5 & $0^{\cdots}$ & 8 & $0 \cdots$ & 8 & $0 \cdots$ & 8 & 7 & 2 & $1>2$ & $1>3$ & Years $1,5>$ Years $2,4>$ Year 3 \\
\hline 2 & 3.8 & & & $0^{*}$ & 7 & 0 & 4 & $10^{\cdots}$ & 0 & $\underline{2>3}$ & $5>3$ & \\
\hline 3 & 0.7 & & & & & $7^{\circ}$ & 0 & $10^{\cdots}$ & 0 & $\overline{4>3}$ & & \\
\hline 4 & 1.6 & & & & & & & $10^{\cdots}$ & 0 & $\overline{5>4}$ & & \\
\hline 5 & 14.7 & & & & & & & H) Long & jaw & udsucker & & \\
\hline 1 & 7.4 & 6 & 2 & $8 \cdots$ & 8 & $0 \cdots$ & 8 & 1 & 5 & $2>3$ & $1>3$ & Years $1,2>$ Year $3>$ Year 4 \\
\hline 2 & 9.4 & & & $0 \cdots$ & 9 & $0^{\cdots}$ & 9 & $0 \cdots$ & 9 & $\overline{3>4}$ & $2>4$ & Year $5>$ Year 4 \\
\hline 3 & 5.9 & & & & & $0^{*}$ & 6 & 5 & 1 & $5>4$ & & \\
\hline 4 & 0.8 & & & & & & & $6^{\circ}$ & 0 & & & \\
\hline 5 & 3.1 & & & & & & & I) Califo & rnia & nguefish & & \\
\hline 1 & 3.2 & $0^{\cdots}$ & 8 & $9 \cdots$ & 0 & 1 & 5 & 0 & 7 & $1>2$ & $3>1$ & Year $3>$ all other Years \\
\hline 2 & 0.6 & & & $10^{\cdots}$ & 0 & $9^{\cdots}$ & 0 & $6^{\cdot}$ & 0 & $3>2$ & $\overline{3>5}$ & Year $1>$ Year $5>$ Year 2 \\
\hline 3 & 7.8 & & & & & $0^{\circ}$ & 7 & $0^{\cdots}$ & 10 & $3>4$ & $4>2$ & Year $4>$ Year 2 \\
\hline 4 & 2.4 & & & & & & & 1 & 6 & & $1>5$ & \\
\hline 5 & 1.7 & & & & & & & (J) Spec & klec & sanddab & & \\
\hline 1 & 1.1 & 0 & 3 & $11 \cdots$ & 0 & 1 & 1 & $6^{\circ}$ & 0 & $3>2$ & $3>1$ & Years $3,5>$ Years $1,2,4$ \\
\hline 2 & 0 & & & $0 \cdots$ & 11 & 3 & 0 & $6^{\cdot}$ & 0 & $3>4$ & $\overline{5>1}$ & \\
\hline 3 & 5.2 & & & & & $0 \cdots$ & 11 & 2 & 8 & $5>4$ & & \\
\hline 4 & 0.8 & & & & & & & $6^{\circ}$ & 0 & & & \\
\hline 5 & 3.8 & & & & & & & & & & & \\
\hline
\end{tabular}


by Year 5: California killifish Fundulus parvipinnis and longjaw mudsucker Gillichthys mirabilis to Site 4, bay pipefish to Site 1 (Fig. 4 a).

At Site 3,5 of the 6 significant year-to-year changes in abundance and number of species were consistent with short-term storm-related effect (Table 4C, G). The 4 significant differences in comparisons of earlier with later minor storm years and earlier with later major storm years all are consistent with persistent stormrelated effects (Table $4 \mathrm{C}, \mathrm{G}$ ). Of the 3 Site 3 associates of Year 1, all continued to be associated with the site (Fig. 4 b), but 2 were significantly reduced in abundance by Year 5 (topsmelt Atherinops affinis and shiner surfperch Cymatogaster aggregata) while the third increased (Speckled sanddab Citharichthys stigmaeus) (Table 5A, B, J). California tonguefish Symphurus atricauda were caught in equal number at Sites 3 and 4 and Year 1 . They were associated with Site 3 in Year 5 and were reduced in number compared to Year 1 (Fig. 4b, Table 5I).

At Site 4 , the 4 significant indications of persistent storm-related effects are made ambiguous by the lack of evidence for short-term storm-related effects (Table $4 \mathrm{D}, \mathrm{H})$. Staghorn sculpin Leptocottus armatus, California halibut Paralichthys californicus, and diamond turbot Hypsopsetta guttulata were Site 4 associates in Year 1. Sculpin and turbot had switched to Site 3 in Year 5 (Fig. $4 \mathrm{c}$ ), but none of the 3 were significantly different in abundance between Years 1 and 5 (Table $5 \mathrm{C}, \mathrm{E}, \mathrm{F})$. Although all experienced significant changes in abundance between years during the study, these changes were not related to the timing of the storms. Thus, sculpin were more abundant in Year 3 than in any other year, halibut were more abundant in Year 4 than in Years 2, 3 and 5, and turbot were more abundant at the beginning and the end of the study than during the intermediate years (Table 5C, E, F).

\section{DISCUSSION}

According to reports of previous workers, the general habitat characteristics of the eastern arm of Mugu Lagoon in the first year of our study were similar to what they had been for at least the preceding $15 \mathrm{yr}$ (MacGinitie and MacGinitie, 1969; Warme, 1971; Peterson, 1977). In the first year the fish fauna was relatively rich in species (36 species caught in all, as many as 19 in $1 \mathrm{mo}$ ) (Fig. 2a) but very heavily dominated by 2 species. Topsmelt and shiner surfperch accounted for 42 and $34 \%$ of the total catch respectively, while the third most common species accounted for only $7 \%$. Abundance and number of species showed peaks in early summer and autumn and were lowest in winter. Monthly values of the Shannon-
Weaver index of species diversity were most commonly 1.2 to 1.4 natural bels but reached a maximum of 1.9 in the autumn, followed the next month by a minimum of 0.3 . With minor changes, the same summary could have been written for almost any other report that we have seen on the annual cycle of diversity and abundance of estuarine fishes, either for other locations in this region (Allen and Horn, 1975; Nybakken, et al., 1977; Horn, 1980) or other temperate or subtropical areas of North America (McErlean, et al., 1973; Oviatt and Nixon, 1973; Haedrich and Haedrich, 1974; Subrahmanyam and Drake, 1975; Cain and Dean, 1976; Livingston, 1976; Hoff and Ibara, 1977). Dahlberg and Odum (1970) differ in that they observed a summertime low in diversity. This general pattern is usually explained as a response to seasonal changes in temperature and salinity. Since appreciable dilutions below marine conditions are reported as rare and transitory in all the cited studies for sites in California, it would appear that the wide and seasonal fluctuations of temperature in shallow coastal water may be a sufficient condition to account for the pattern elsewhere as well.

We can explain most of the changes observed in the fish fauna of Mugu Lagoon over the 5 yr from February 1977 to February 1982 in terms of the major changes wrought upon the lagoon by major storms at the ends of Years 1 and 3. The abruptness and magnitude of the alterations, the differential effects on different sites and the replication of the process in 2 yr blocks allow identification of causal connections that would be unrecognizable with gradual changes. For the lagoon as a whole, the abundance and number of species of fish caught in major storm years were significantly lower than in preceding and succeeding minor storm years in every case (Year $1>2<3>4<5$ ), strongly suggesting short-term storm-related effects (Table 1A, B). Longer term effects were evident in the ShannonWeaver indices of diversity $\left(\mathrm{H}^{\prime \prime}\right)$ and evenness $\left(\mathrm{J}^{\prime \prime}\right)$, as well as in abundance and number of species. Thus, $\mathrm{H}^{\prime \prime}$ declined from Year 1 to Years 2, 3, 4 and then rose to its highest level in Year 5 (Table 1D). Different factors are responsible for the changes at the beginning and the end of the study, respectively. The species richness component ( $\mathrm{S}$, Table $1 \mathrm{C}$ ) is responsible for the decline from Year 1 to the intermediate years, since evenness $\left(\mathrm{J}^{\prime \prime}\right)$ did not change significantly during the period (Table 1E). Increased evenness was responsible for the net increase in $\mathrm{H}^{\prime \prime}$ between Years 1 and 5, since the number of species was down in this comparison (Table $1 \mathrm{E}$ vs. $1 \mathrm{C}$ ). The increase in evenness from Year 1 to Year 5 is explained by the significant decreases in abundance of the 2 most common species of Year 1 , topsmelt and shiner surfperch, while the 6 species ranking next in abundance were not significantly dif- 
ferent in Years 1 and 5 (Table 5). Net declines from Year 1 to Year 5 in both abundance and number of species indicate the persistence of storm-related effects.

Another indication that the major storms were responsible for the changes observed in the fish fauna is that the fish community changed the most at the sites that were affected most by the storms (at least in terms of the factors that we could document). Thus, stormrelated reductions in abundance and/or number of species were observed at Sites 2 and 3, as well as declines or switches to other sites in 5 of the 6 species originally associated with these sites (Tables $4 \mathrm{~A}, \mathrm{~B}, \mathrm{E}$, $\mathrm{F}$ and $5 \mathrm{~A}, \mathrm{~B}_{i}$ Fig. $4 \mathrm{a}, \mathrm{b}$ ). These sites had experienced major reductions in depth, grain size of the substrate and cover by eelgrass. In contrast, the only negative changes observed at the less affected sites (Site 1, increased cover by eelgrass, and Site 4, decreased depth) were a possible decline in number of species at Site 4 and the switch to another site of 2 of the 3 Site 4 associates of Year 1.

The histories of the common species considered individually provide information on which changes of the lagoon environment most influenced the fish community and how. Our initial impression was that the reduction in grain size of the superficial sediments was the most severe and extensive alteration of the lagoon caused by the major storms. If this were a major determinant of the structure of the fish community, demersal species (those that spend the great majority of their time on or near the bottom) should have responsed strongly: those associated with coarser substrates declining and those associated with finer substrate increasing. In fact, of the 7 demersal species common enough for individual analysis, only 1 changed in abundance consistent with storm-related effects: the sixth most abundant, California tonguefish. The timing of changes in abundance of the remainder cannot be explained by the storms (Table 5 and Fig. 2c: staghorn sculpin, California killifish, California halibut, diamond turbot, longjaw mudsucker and speckled sanddab).

As well as altering the texture of the bottom of the lagoon, the sediments deposited by the storms have decreased the depth of the lagoon by $19 \mathrm{~cm}$, on average (Table 2 ). This amounted to a $38 \%$ reduction in the volume of water retained at low tide. If this alteration influenced the structure of the fish community, it would be by reducing the abundance of species that occupy the water column rather than rest on the bottom. (Sediment deposition was much greater in deep than shallow areas. Therefore, the area of bottom submerged at low tide changed proportionately less than volume.) Apparently, this is an important factor, because all 3 of the common species that occupy the water column: topsmelt, shiner surfperch, and bay pipefish, responded strongly to the major storms. Since the effect of depth is confounded with changes in cover by eelgrass for the latter 2 species, this factor will be considered before returning to the role of depth.

The thick layer of new sediments deposited in 1978 instantly buried the short-bladed eelgrass that grew in areas of shallow water, such as Site 2, and apparently was responsible for the gradual deterioration and eventual extermination of the long-bladed eelgrass that grew in areas of deeper water, such as Site 3 . The close synchronization of changes in the abundances of bay pipefish and shiner surfperch with the changes in eelgrass at these sites, respectively, clearly demonstrates the influence of eelgrass on the structure of the fish community. Thus, in Year 2 bay pipefish were reduced in number (Table 5G), had abandoned Site 2 almost entirely and occurred almost exclusively at Site 3 (Fig. 4a) where some eelgrass still survived. In Year 3 , with eelgrass now absent at Site 3 as well, only 8 individuals were caught in the whole lagoon. The increases in Year 4 and again in Year 5 were concentrated at Site 1, where an eelgrass bed was proliferating in shallow water (Fig. 4a). Shiner surfperch continued their association with Site 3 in Year 2 (Fig. 4b), in fact being twice as abundant in June 1978 as in June 1977, but then they abandoned the lagoon earlier than in the preceding year and have remained rare since (Fig. 2c).

Although the location and condition of eelgrass beds in Mugu Lagoon are crucial in explaining the population dynamics of bay pipefish and shiner surfperch, the explanation is not complete without also considering depth. The difference in the performances of the 2 species since February 1978 appears to be either that water of sufficient depth for shiner surfperch no longer exists in the lagoon or that eelgrass as yet has not grown back thickly enough in deep water. In contrast, the regrowth of eelgrass in shallow water has been enough for bay pipefish to achieve similar abundances to Year 1, but at a new location.

Topsmelt, the remaining common occupant of the water column in Mugu Lagoon, was the most abundant species in this study. For the first $4 \mathrm{yr}$, abundances followed the general pattern of high numbers in minor storm years and lower numbers in major storm years, suggesting short-term storm-related effects; however, the only significant difference was between Years 1 and 2. Also, there was a decline rather than an increase from Year 4 to Year 5 (Table 5A). This weakens the interpretation that the significant difference between minor Storm Years 1 and 5 is evidence for a persistent storm-related effect caused by the decreased depth of the lagoon; however, other data are supportive. Ranked monthly comparisons of the 7 mo sampled 
since the end of Year 5 (March to September 1982 without a major storm) with the same months of Year 1 show that the abundance of topsmelt remains significantly lower than in Year 1 (all 7 mo of similar rank were lower in Year 6). Thus, the reduction in the abundance of topsmelt is long-lasting. The decreased depth, hence low-tide volume, of the lagoon by itself may be a sufficient explanation for the decline, especially if the differentially filled deeper areas were most important. Depth decreased $38 \%$ while the number of topsmelt caught decreased $57 \%$ between Years 1 and 5. Also, abundances were in the same rank order as average depth of sampling sites in Year 1 $(1<2<4<3)$. The differential deposition of sediments has changed the order of sites ranked by depth, and the order of sites by catch of topsmelt has changed accordingly $(2<4<1<3)$.

\section{Differences in storm-related effects}

We have reported large alterations to the eastern arm of Mugu Lagoon originating from major storms in 1978 and 1980. These changes are unprecedented in recent times, even though more extreme storms have occurred. For instance, MacGinitie and MacGinitie (1969) witnessed the effects of the storm of 7 to 12 February 1962 when $26 \mathrm{~cm}$ of rain fell in 5 d, compared to $20 \mathrm{~cm}$ in $9 \mathrm{~d}$ in 1978 and in 1980. Although they noted the deposition of 'from 5 to 6 inches of loose mud over the bottom of the large basin' (Central Basin, Fig. 1) and complete mortality of the invertebrates there, they also reported that the runoff 'was carried to sea without affecting the south arm of the lagoon [eastern arm in our terminology, Fig. 1] to any appreciable extent' (p. 15).

Twenty-nine $\mathrm{cm}$ of precipitation fell in January 1969, $24 \mathrm{~cm}$ in a 9-d period, in between the extensive studies of Warme (1966) and Peterson (1975, 1977). Peterson inferred that this storm had caused largescale mortality of the sand dollar Dendraster excentricus from the preponderance of small individuals in his first samples collected later that year; however, he indicated no habitat changes from those described by Warme. We now know from the long persistence of the 1978 and 1980 storm-related alterations that Peterson would have seen major differences if sedimentation had occurred.

Four factors alone or together may have accounted for the enhanced effects of the later, somewhat smaller storms. (1) If storms coincide with neap tides, they will not affect the eastern arm. Under these conditions, the only connection between the central basin, where the main inlet stream empties its load of fresh, sedimentladen water, and the eastern arm is through the narrow sand channel (Fig. 1). There is little flow into the eastern arm, because the rise in tide is small. In contrast, on spring tides the whole marsh will be flooded by at least $30 \mathrm{~cm}$ of water. When this happens, there is an unobstructed path for the sediment-laden water straight from the creek into the eastern arm (Fig. 1). Perhaps most importantly, the volume of water from which particulates could be sedimented (the tidal prism) is much greater during spring than neap tides. From our 3 surveys which included the marsh as well as the lagoon, we estimate that the tidal prism on a spring tide is 3.7 times the prism on a neap tide. Apparently. spring tides are a necessary but not a sufficient condition for major effects in the eastern arm. The 1978 and 1980 storms both coincided with spring tides, but so did one of the storms (1969) that did not cause heavy sedimentation. (2) In 1978, the February storm had been preceded by the fourth wettest January in 32 years of meteorological observations at Pt. Mugu Naval Air Station, which in turn followed 3 yr of subnormal precipitation (deViolini, 1976 and pers. comm.). Since runoff is greater when a soil is saturated, erosion will also be greater when precipitation falls on an already saturated watershed (Leopold et al., 1964). The susceptibility to erosion would be aggravated by the poor condition of the vegetation after sustained drought. (3) Large-scale residential and commercial development of the upper parts of the watershed have pre-empted the valley bottoms and forced citrus groves and subsequent residential development onto steep slopes, thus increasing the susceptibility of the watershed to erosion and downstream areas to sedimentation (Prestegaard, 1979). This effect is consistent with the increased sedimentation caused by the recent storms, because aerial photographs showed that large tracts of the hilly terrain were being developed and bare in 1979. Comparisons with the USGS topographic sheet for the same area indicated that of hillside areas developed in 1979, $25 \%$ had been developed by 1947 , another $15 \%$ was developed in the 22 yr to 1969 , and the remaining $60 \%$ was developed in only $10 \mathrm{yr}$ : 1969 to 1979. (4) The central basin was dredged in 1952 and 1961 to a depth of $9 \mathrm{~m}$ to provide fill for the construction of the naval air station (Steffen, 1982). Deposition in this basin until it was filled would have buffered the eastern arm from siltation. Apparently this buffering capacity was exceeded during the 1978 storm. This is borne out by aerial photographs of the lagoon. As late as January 1977 only a minor delta was present in the central basin at the mouth of Calleguas Creek. In May 1978 the central basin was almost completely filled (Fig. 5).

On the basis of these observations, we conclude that at least the proximate cause of the unprecedented effects of the 1978 and 1980 storms, despite more 

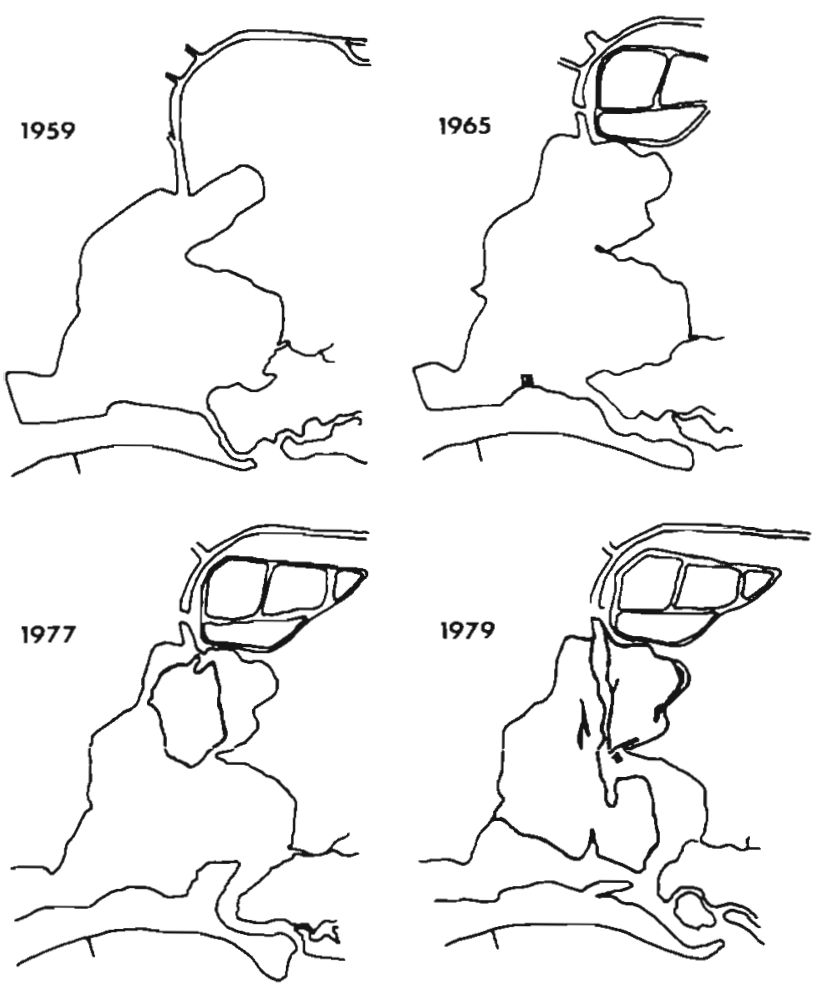

Fig. 5. Extent of intertidal flats (stippled) within the central basin of Mugu Lagoon on different dates from 1959 to 1979

severe storms occurring in 1962 and 1969, is that the storms not only coincided with spring tides but also the sink for sediments provided by the central basin was filled before the end of the 1978 storm. The climatic pattern immediately preceding the 1978 storm and changes in land use in the upper reaches of the watershed may have aggravated erosional processes, thereby augmenting the supply of sediments; however, these probably were not the main causes of the major changes in the eastern arm.

\section{Comparisons with other regions}

Two published reports of estuarine fish community structure span periods comparable to this study. Moore (1978) reported total abundance and various indices of diversity for one date each summer from 1966 to 1973 for Aransas Bay, Texas. Duplicated day and night samples were taken at 2 stations in the bay and pooled for the analysis. Lowest diversities $\left(\mathrm{H}^{\prime \prime}\right)$ were measured in the $2 \mathrm{yr}$ following a hurricane. Since we and others have recorded bigger differences between summer months in the same year than he reported over $8 \mathrm{yr}$, it is not certain how to interpret these results. In contrast to our findings in the aftermath of a major storm, Moore observed no reduction in abundance or number of species.
McErlean et al. (1973) detected a long-term decline in abundance and in every measure of diversity that they considered in their analysis of $4 \mathrm{yr}$ of quarterly fish collections from a very extensive sampling grid on the Patuxent River, Maryland. They could identify no cause and saw no clear evidence of an effect of the point source of pollution (the hot water discharge of a power plant) that was the focus of the investigation. They inferred that a 'generalized environmental degradation' was responsible. In our study the discrete nature of the perturbation allowed us to trace its mode of operation on the fish community and interpret a downward trend in terms other than a generalized environmental degradation'. Considering the subtlety and complextiy of the responses to this major but discrete disruption of the system, it is not surprising that cause and effect can only be conjectured in most studies.

Recently, the importance of rare, extreme natural events in determining the structure of natural communities has been proposed (Wiens, 1977) and quite convincingly demonstrated in some systems (Connell, 1978). In these reports and those which have considered the role of disturbance on a smaller scale (such as Dayton, 1971; Levin and Paine, 1974; Sousa, 1979) the effect of the disturbances has been to disrupt the biological community before competitive processes could run their full course. The changes are primarily in the biotic component of the ecosystem. In our study, the changes were not limited to the biota but extended to the physical environment as well. Since many kinds of human modifications to natural systems are through long-lasting changes to the physical environment (bulkheading channels, continuously pouring into the environment effluents that differ in temperature, chemical composition, or particle concentration from that of the receiving medium) our observations may be more relevant to man-environment problems than those situations in which disturbance interrupts progress toward a seldom achieved equilibrium. Stability analyses (Holling, 1973) may not be appropriate where irreversible physical alterations are important. The role of irreversible change is more closely akin to the recent re-interpretation of hydrarch succession as being largely a passive response of the vegetaion to changes caused by weathering and water transport rather than caused by the vegetation itself (Walker, 1970; Colinvaux, 1973), with the amendment that the alterations occur as episodic, extreme events rather than gradual accretion.

Both characteristics of the changes that we have documented in this report, their irreversibility and their episodic occurrence, probably will apply to the other lagoon systems of the Pacific Coast of North America from the Tropic of Cancer to San Francisco 
Bay, and perhaps to other coasts where Mediterranean climates prevail. Rare episodes of major flooding and sedimentation are the norm in this region of highly seasonal, highly variable and highly concentrated precipitation falling on sparsely vegetated, steep slopes of easily eroded geological formations. The steepness of the coastal region eliminates the possibility that losses by filling on the landward side of embayments may be compensated by gains on the seaward side through the migration of barrier spits or islands (Shepard and Wanless, 1971). The rare episodes of major sedimentation that occur when extremely heavy rains coincide with spring tides should produce a step-wise shoaling of these small coastal lagoons. According to our observations, each episode will cause a sharp reduction in the abundance of fishes, followed by an increase that will not achieve previous levels. Species that spend most of their time in the water column rather than on the bottom will decline the most. The deepest parts of the lagoons will fill the fastest. Land use in the surrounding watershed will influence the severity of these effects. All of these factors should be considered in the management of these systems.

In coastal regions of low relief, we suspect that the component of irreversible change will be less important than in our system; however, the component of infrequent but major disturbance may well be more important in these systems than is commonly recognized. There is evidence from a north Florida estuary that long-term cyclic fluctuations in the fish fauna and the rest of the biota can be linked to periodicity in extreme climatic events (R. J. Livingston, pers. comm.).

Acknowledgements. We thank US Naval Air Station, Pt. Mugu, California, for permission to conduct research in the lagoon, and Base Biologist Ron Dow and Meteorologist Bob deViolini for providing essential supporting data. Dr. Milton Love assisted with initial identifications of the fishes. Comments by R. Black, R. Otto, C. Peterson, W Sousa and 3 anonymous reviewers have improved this version. This research was sponsored in part by NOAA, National Sea Grant College Program, Dept. of Commerce, under Grants \#04-7158-44121 and NA80AA-D-00120, Projects \#R/CZ-33A and 52 through the California Sea Grant College Program, and the California State Resources Agency. The US Government is authorized to produce and distribute reprints for governmental purposes notwithstanding any copyright notation that may appear hereon.

\section{LITERATURE CITED}

Allen, L. G., Horn, M. H. (1975). Abundance, diversity and seasonality of fishes in Colorado Lagoon, Alamitos Bay, California. Estuar coast. mar. Sci. 3: 371-380

Cain, R. L., Dean, J. M. (1976). Annual occurrences, abundance, and diversity of fish in a South Carolina intertidal creek. Mar. Biol. 36: 369-379

California Coastal Zone Conservation Commissions (1975). California coastal plan. Sacramento, California
Colinvaux, P. A. (1973). Introduction to ecology. John Wiley \& Sons, Inc., New York

Connell, J. H. (1978). Diversity in tropical rain forests and coral reefs. Science, N. Y 199: 1302-1310

Dahlberg, M. D., Odum, E. P. (1970). Annual cycles of species occurrence, abundance and diversity in Georgia estuarine fish populations. Am. Midl. Nat. 83: 381-392

Dayton, P. K. (1971). Competition, disturbance and community organization: the provision and subsequent utilization of space in a rocky intertidal community. Ecol. Monogr. 41: 351-389

deViolini, R. (1976). Climatic summary for the Pacific Missile Test Center, PMTC Geophysics Division, Pt. Mugu, California

Haedrich, R. L., Haedrich, S. O. (1974). A seasonal survey of the fishes in the Mystic River, a polluted estuary in downtown Boston, Massachusetts. Estuar. coast. mar. Sci. 2: $59-73$

Hoff, J. G., Ibara, R. M. (1977). Factors affecting the seasonal abundance, composition and diversity of fishes in a southeastern New England estuary. Estuar. coast. mar. Sci. 5: $665-678$

Holling, C. S. (1973). Resilience and stability of ecological systems. Ann. Rev. Ecol. Syst. 4: 1-23

Horn, M. H. (1980). Diel and seasonal variation in abundance and diversity of shallow-water fish populations in Morro Bay, California. Fish. Bull. 78: 759-770

Leopold, L. B., Wolman, M. G., Miller, J. P. (1964). Fluvial processes in geomorphology. W. H. Freeman, San Francisco

Levin, S. A., Paine, R. T. (1974). Disturbance, patch formation and community structure. Proc. natn. Acad. Sci. U.S.A. 68 : $1246-1248$

Livingston, R. J. (1976). Diurnal and seasonal fluctuations of organisms in a north Florida estuary. Estuar. coast. mar. Sci. 4: $373-400$

Macdonald, K. B. (1976). The natural resources of Mugu Lagoon. California Department of Fish \& Game, Coastal Wetlands Series 17: 1-119

MacGinitie, G. E., MacGinitie, N. L. (1969). A report on Mugu Lagoon. The Tabulata 2: 15-24

McErlean, A. J., O'Connor, S. G., Mihursky, J. A., Gibson, C. I. (1973). Abundance, diversity and seasonal patterns of estuarine fish populations. Estuar. coast. mar. Sci. 1: 19-36

Moore, R. H. (1978). Variations in the diversity of summer estuarine fish populations in Aransas Bay. Texas, 1966-1973. Estuar. coast. mar. Sci. 6: 495-501

Nybakken, J., Cailliet, G., Broenkow, W. (1977). Ecologic and hydrographic studies of Elkhorn Slough, Moss Landing Harbor and nearshore coastal waters, July 1974 to June 1976. Technical Report, Moss Landing Marine Laboratories, Moss Landing, California

Onuf, C. P. (1980). Guidelines for the protection of the natural resources of California's coastal wetlands: proceedings of a workshop on coastal wetlands management held at University of California, Santa Barbara, 24-26 May 1979. California Coastal Commission, San Francisco

Onuf, C. P. (in prep.). Demography and production of Salicornia virginica $\mathrm{L}$. in a southern California salt marsh.

Onuf, C. P., Quammen, M. L., Shaffer, G. P., Peterson, C. H., Chapman, J. W., Cermak, J., Holmes, R. W. (1979). An analysis of the values of central and southern California coastal wetlands. In: Greeson, P. E., Clark, J. R., Clark, J. E. (eds.) Wetland functions and values: the state of our understanding. American Water Resources Association, Minneapolis, Minnesota, p. 186-199 
Oviatt, C. A., Nixon, S. W. (1973). The demersal fish of Narragansett Bay: an analysis of community structure distribution and abundance. Estuar. coast. mar. Sci. 1: 361-378

Peterson, C. H. (1975). Stability of species and of community for the benthos of two lagoons. Ecology 56: 958-965

Peterson, C. H. (1977). Competitive organization of the softbottom macrobenthic communities of southern California lagoons. Mar. Biol. 43: 343-359

Peterson, C. H., Andre, S. V. (1980). An experimental analysis of interspecific competition among marine filter feeders in a soft-sediment environment. Ecology 61: 129-139

Prestegaard, K. (1979). Stream and lagoon channels of the Los Penasquitos Lagoon. California Coastal Commission, San Francisco

Shepard, F. P., Wanless, H. R. (1971). Our changing coastlines. McGraw-Hill, New York

Sousa, W. P. (1979). Disturbance in marine intertidal boulder fields: the nonequilibrium maintenance of species diver- sity. Ecology 60: 1225-1239

Steffen, L. J. (1982). Mugu Lagoon and its tributaries, geology and sedimentation. USDA Soil Conservation Service, Davis, California

Subrahmanyam, C. B., Drake, S. H. (1975). Studies on the animal communites in two north Florida salt marshes. Part I. Fish communities. Bull. mar. Sci. 25: 445-465

Walker, D. (1970). Direction and rate in some British postglacial hydroseres. In: Walker, D., West, R. (eds.) The vegetational history of the British Isles. Cambridge University Press, Cambridge, p. 117-139

Warme, J. E. (1966). Paleoecological aspects of the recent ecology of Mugu Lagoon, California. Ph. D. thesis, University of California, Los Angeles

Warme, J. E. (1971). Paleoecological aspects of a modern coastal lagoon. Univ. Calif. Publs geol. Sci. 87: 1-131

Wiens, J. A. (1977). On competition and variable environments. Am. Scient. 65:590-597

This paper was presented by Professor J. S. Pearse; it was accepted for printing on February 5, 1983 